\title{
TREATMENT OF MENOPAUSAL SYMPTOMS : A COMPARATIVE STUDY
}

\author{
Gynaecology \\ Dr. Pushpa* $\quad$ Senior Resident, Dept. of Obst \& Gynae, P.M.C.H., Patna. *Corresponding Author \\ Dr. Shilpa Junior Resident, Dept. of Obst \& Gynae, P.M.C.H., Patna. \\ Dr. Rajani Sinha Professor, Dept. of Obst \&Gynae, P.M.C.H., Patna.
}

\section{ABSTRACT}

Menopause is permanent cessation of menstruation resulting from the loss of ovarian follicular activity. Women suffer many troublesome problems after menopause resulting from estrogen deficiency. Aim of this study is to compare symptomatic response in Indian women using different medicine preparations for treatment of menopausal symptoms. It is an observational prospective study conducted in PMCH Gynae OPD from October 2017 to September 2019. Two hundred women were enrolled and assigned to different treatment groups. There was $90.32 \%$ decrease in hot flushes in E2V group while it was $87.09 \%$ in CEE group. Psychosomatic symptoms reduced by $75 \%$ and $70 \%$ in E2V and CEE group respectively. Sexual and urinary symptoms also got more improved when treated with estrogen preparations. Both estradiol valerate and conjugated estrogen were effective in reducing severity of hot flushes, psychosomatic symptoms, sexual and urinary symptoms as compared to isoflavones and placebo. Isoflavones had very little advantage over placebo

\section{KEYWORDS}

Menopause, estradiol valerate, conjugated estrogen, isoflavones

\section{INTRODUCTION}

Menopause is permanent cessation of menstruation due to loss of ovarian function ${ }^{1}$. A wide variety of symptoms have been attributed to the menopause. Besides the classical vasomotar symptoms (hot flushes and night sweats), urogenital symptoms like vaginal dryness, dyspareunia and varying degrees of incontinence are common. Sleeping problems anxiety depression are described, as well as fatigue, muscle and joint pain, drying of the skin, loss of energy, loss of libido and many others symptoms and problems ${ }^{2}$.

\section{AIM AND OBJECTIVES}

Aim of this study is to compare symptomatic response in menopausal women to different treatments. This is a prospective study done at PMCH Patna in duration of 2 years between October 2017 to September 2019.

\section{MATERIALAND METHODS}

This is an observational prospective study done at dept of obstetric and gynaecology, PMCH Patna, Bihar in a duration of 2 years. Two hundred patients who attended OPD and IPD of obstetric and gynaecology department with menopausal symptoms were included in the study.

Tobacco or alcohol abusers, patients with abnormal mammogram, patients having conditions where estrogen preparations are contraindicated were excluded

Patients were divided in 4 groups

Grp A treated with estradiol valerate $0.5 \mathrm{mg}$ daily for 24 weeks. Patients with intact uterus were combined with natural micronized progesterone tabs.

Grp B treated with conjugated equine estrogen $0.625 \mathrm{mg}$ for 24 weeks. Grp C treated with isoflavones $60 \mathrm{mg}$ daily.

Grp D were given placebo.

All patients were informed regarding procedure necessity and duration of treatment. History examinations and relevant medical records duly registered. Patients were followed up at 12 and 24 weeks.

For Statistical significance of variables were determined by Chisquare, Fisher's exact test, and P value less than 0.05 was considered statistically significant

\section{OBSERVATIONS :-}

Among 200 patients 124 patients had hot flushes 156 patient psychosomatic symptoms, 100 sexual symptoms and 100 patients had urinary symptoms.

Mean age of patients receiving E2 V in group $\mathrm{A}$ is 46.08 years while in
Group B receiving CEE the mean age is 47.34 years. In Group C patients receiving Flavones mean age is 49.42 years. In Group D patients receiving Placebo mean age is 54.42 years.

22 patients were in < para 3 group, 80 patients were para 3, 49 were $\mathrm{P} 4,31$ were $\mathrm{P} 5$, and 18 were $\mathrm{P} 6$.

Symptomatic response at 12 and 24 weeks from starting of treatment :

Table - 1 Response In Hotflushes In Different Treatment

\begin{tabular}{|c|c|c|c|c|c|c|}
\hline $\begin{array}{c}\text { TREATMENT } \\
\text { GIVEN }\end{array}$ & $\begin{array}{c}\text { SYMPTOMATIC } \\
\text { PATIENTS AT 0 } \\
\text { WEEKS }\end{array}$ & $\begin{array}{c}\text { SYMPTOM } \\
\text { ATIC } \\
\text { PATIENTS } \\
\text { AT 12 } \\
\text { WEEKS }\end{array}$ & $\begin{array}{c}\text { SYMPTOMATI } \\
\text { C PATIENTS } \\
\text { AT 24 WEEKS }\end{array}$ \\
\cline { 2 - 7 } & No. of Cases & $\%$ & $\begin{array}{c}\text { No. of } \\
\text { Cases }\end{array}$ & \% & $\begin{array}{c}\text { No. of } \\
\text { Cases }\end{array}$ & $\%$ \\
\hline $\begin{array}{c}\text { (A) Estradiol } \\
\text { Valerate E2V }\end{array}$ & 31 & 100 & 10 & 32.25 & 3 & 9.67 \\
\hline $\begin{array}{c}\text { (B) Conjugated } \\
\text { estrogen CEE }\end{array}$ & 31 & 100 & 12 & 38.71 & 4 & 12.90 \\
\hline (C) Isoflavones & 31 & 100 & 16 & 51.61 & 12 & 38.71 \\
\hline (D) Placebo & 31 & 100 & 22 & 78.96 & 18 & 58.06 \\
\hline
\end{tabular}

In grp A receiving E2V $90.33 \%$ got relieved of symptoms at the end of 24 weeks while in grp B receiving CEE $87.1 \%$ got relief. In isoflavone grp C $61.29 \%$ patients got symptomatic relief. In grp D it was only $41.94 \%$.

Table -2 Relief In Psychosomatic Symptoms In Different Treatment

\begin{tabular}{|c|c|c|c|c|c|c|}
\hline \multirow[t]{2}{*}{$\begin{array}{l}\text { TREATMENT } \\
\text { GIVEN }\end{array}$} & \multicolumn{2}{|c|}{$\begin{array}{l}\text { SYMPTOMAT } \\
\text { IC PATIENTS } \\
\text { AT O WEEKS }\end{array}$} & \multicolumn{2}{|c|}{$\begin{array}{l}\text { SYMPTOMA } \\
\text { TIC } \\
\text { PATIENTS AT } \\
12 \text { WEEKS }\end{array}$} & \multicolumn{2}{|c|}{$\begin{array}{l}\text { SYMPTOMA } \\
\text { TIC } \\
\text { PATIENTS AT } \\
24 \text { WEEKS }\end{array}$} \\
\hline & $\begin{array}{l}\text { No. of } \\
\text { Cases }\end{array}$ & $\%$ & \begin{tabular}{|l|} 
No. of \\
Cases
\end{tabular} & $\%$ & $\begin{array}{l}\text { No. of } \\
\text { Cases }\end{array}$ & $\%$ \\
\hline $\begin{array}{l}\text { (A) Estradiol } \\
\text { Valerate E2V }\end{array}$ & 40 & 100 & \begin{tabular}{|l|}
12 \\
\end{tabular} & 30 & 10 & 25 \\
\hline $\begin{array}{l}\text { (B) Conjugated } \\
\text { estrogen CEE }\end{array}$ & 40 & 100 & 20 & 50 & 10 & 25 \\
\hline (C) Isoflavones & 38 & 100 & 27 & 67.5 & 22 & 55 \\
\hline (D) Placebo & 38 & 100 & 28 & 70 & 26 & 65 \\
\hline
\end{tabular}

In E2V group 30\% patients remained symptomatic at 12 weeks and $25 \%$ at 24 weeks. In both E2V \& CEE groups $75 \%$ patients had relief in symptoms at the end of 24 weeks. While in Isoflavones group $55 \%$ and in Placebo group 65\% patients remain symptomatic at 24 weeks. 
TABLE - 3Response in sexual symptoms in different treatment

\begin{tabular}{|l|l|l|l|l|l|l|}
\hline $\begin{array}{l}\text { TREATMENT } \\
\text { GIVEN }\end{array}$ & $\begin{array}{l}\text { SYMPTOMA } \\
\text { TIC } \\
\text { PATIENTS } \\
\text { AT 0 WEEKS }\end{array}$ & $\begin{array}{l}\text { SYMPTOMA } \\
\text { TIC } \\
\text { PATIENTS AT } \\
\text { 12 WEEKS }\end{array}$ & $\begin{array}{l}\text { SYMPTOMAT 24 WEEKS } \\
\text { IC PATIENTS } \\
\text { AT 24 }\end{array}$ \\
\cline { 2 - 7 } & $\begin{array}{l}\text { No. of } \\
\text { Cases }\end{array}$ & $\begin{array}{l}\text { No. of } \\
\text { Cases }\end{array}$ & $\begin{array}{l}\text { No. of } \\
\text { Cases }\end{array}$ & $\%$ \\
\hline $\begin{array}{l}\text { (A) Estradiol } \\
\text { Valerate }\end{array}$ & 30 & 100 & 17 & 56.6 & 12 & 40 \\
\hline $\begin{array}{l}\text { (B) Conjugated } \\
\text { estrogen }\end{array}$ & 30 & 100 & 18 & 60 & 13 & $\begin{array}{l}\text { \% } \\
\text { (C) Isoflavones }\end{array}$ \\
\hline (D) Placebo & 20 & 100 & 15 & 75 & 14 & 70 \\
\hline
\end{tabular}

At 24 weeks in group A,B,C\& D, 40\%, 43.33\%, 70\%, 90\% remain symptomatic at 24 weeks respectively.

Table - 4 Urinary Symptoms Response In Different Treatment Groups

\begin{tabular}{|c|c|c|c|c|c|c|}
\hline \multirow[t]{2}{*}{ TREATMENT GIVEN } & \multicolumn{2}{|c|}{\begin{tabular}{|l|} 
SYMPTO \\
MATIC \\
PATIENT \\
S AT 0 \\
WEEKS \\
\end{tabular}} & \multicolumn{2}{|c|}{$\begin{array}{l}\text { SYMPTOM } \\
\text { ATIC } \\
\text { PATIENTS } \\
\text { AT 12 } \\
\text { WEEKS } \\
\end{array}$} & \multicolumn{2}{|c|}{\begin{tabular}{|l} 
SYMPTOM \\
ATIC \\
PATIENTS \\
AT 24 \\
WEEKS \\
\end{tabular}} \\
\hline & $\begin{array}{l}\text { No. of } \\
\text { Cases }\end{array}$ & $\%$ & $\begin{array}{l}\text { No. of } \\
\text { Cases }\end{array}$ & $\%$ & $\begin{array}{l}\text { No. of } \\
\text { Cases }\end{array}$ & $\%$ \\
\hline $\begin{array}{l}\text { (A) Estradiol Valerate } \\
\text { E2V }\end{array}$ & 35 & 100 & 14 & 40 & 11 & 31.43 \\
\hline $\begin{array}{l}\text { (B) Conjugated estrogen } \\
\text { CEE }\end{array}$ & 35 & 100 & 15 & 42.86 & 11 & 31.43 \\
\hline (C) Isoflavones & 15 & 100 & 12 & 80 & 11 & 73.33 \\
\hline (D) Placebo & 15 & 100 & 12 & 80 & 12 & 80 \\
\hline
\end{tabular}

In both group A \& B 31.43 patients remain symptomatic. In C \& E group $73.33 \%$ and $80 \%$ patients still had symptoms at 24 weeks respectively.

\section{DISCUSSION :-}

In this study $62 \%$ patients had hot flushes. Maximum patients of hot flushes were treated with estrogen preparations. this finding is comparable with Madhu Kumar et al ${ }^{[3]}$ (2012, Bengaluru) and Dutta et $\mathrm{al}^{[4]}$ (2012, Tamil Nadu), in which prevalence was $55.9 \%$ and $60.9 \%$ respectively. The therapeutic value of estrogen preparations are superior to other treatment groups . Cochrane review of a randomized trial showed $75 \%$ reduction in hot flushes with estrogen therapy. In this study $90.33 \%$ and $80.1 \%$ patients got relieved of vasomotor symptoms in E2V and CEE group respectively.

Psychosomatic problems had significant reduction by treatment with estrogen preparations in last 3 month of duration of treatment. Relief was more in estrogen group $75 \%$, while isoflavones showed relief in $45 \%$ only. In the present study $50 \%$ women had one or more sexual problems which is comparable to study of Madhu Kumar et al ${ }^{[3]}$ $(48.2 \%)$. Patients were found very shy of discussing sexual symptoms. Nevertheless there was significant improvement in E2V group (60\%) as compared to isoflavone group.

There was much more improvement in urinary symptoms (58.47\%) in estrogen group while in Group C and D patients remained largely symptomatic, more than $70 \%$.

P. Value was significant $(<0.05)$ for estrogen groups.

\section{CONCLUSION :-}

Low doses of CEE and E2V are equally effective for vasomotor and vaginal symptoms when administered over 24 weeks. CEE offers no advantage over physiological estradiol. So use of E2V is considered more appropriate which is less costly. No serious side effects were reported in both $\mathrm{E} 2 \mathrm{~V}$ and $\mathrm{CEE}$ group. Isoflavones have some effect but is not comparable to estrogen preparations. Awareness regarding menopause and associated health issues should be created in community as a whole and appropriate treatment should be started whenever required.

\section{REFERENCES :-}

1. Shaw's Textbook of Gynaecology, $16^{\text {th }}$ Edition : 65-78.

2. Barton M, Dubey RK (2002) Postmenopausal hormone replacement therapy. N Engl J Med 346:63-65
3. Madhukumar S, Gaikwad V, Sudeepa D. A community based study on perception about menopausal symptoms and quality of life of post menopausal women in Banglore rural: ijhsrVol.2; Issue: 3 ; June 2012.

4. Ruma Dutta et al., A Population Based Study on the Menopausal Symptoms in Rural Areas of Tamil Nadu. Journal of Clinical and Diagnostic Research. 2012 May (Suppl-2), Vol-6(4): 597-601

5. Lippert TH, Mueck AO, Seeger H (2000) is the use of conjugated equine oestrogens in hormone replacement therapy still appropriate? Br J Clin Pharmacol 498(5): 489-490.

6. Malik, S, Pannu, D., Prateek, S. et al. Comparison of the symptomatic response in Indian menopausal women with different estrogen preparations for the treatment of menopausal symptoms: a randomized controlled trial. Arch GynecolObstet 293, 1325 $1333(2016)$

7. American College of Obstetricians and Gynecologists (2014) ACOG practice bulletin no. 141: management of menopausal symptoms. ObstetGynecol 123:202-216.

Grady D (2006) Clinical practice. Management of menopausal symptoms. N Engl J Med Grady D (2006)

355:2338-2347.
Crandall C. Low-dose estrogen therapy for menopausal women: a review of efficacy and safety. J Womens Health (Larchmt). 2003;12(8): 723-747.

10. Carmignani LO, Pedro AO, Costa-Paiva LH, Pinto-Neto AM. The effect of dietary soy supplementation compared to estrogen and placebo on menopausal symptoms: a randomized controlled trial. Maturitas. 2010;67(3):262-269. 